\title{
Moderasi Beragama: Arah Baru Pendidikan Agama Islam (PAI)
}

\author{
Rahmad Hidayat \\ Institut Agama Islam Negeri Curup \\ rahmadhidayat@iaincurup.ac.id
}

\begin{abstract}
This study aims to examine the essence of the Decree of the Minister of Religion (KMA) number 183 of 2019. KMA 183 of 2019 concerning the Islamic and Arabic religious education curriculum in Madrasah is set by the Minister of Religion to be implemented starting from the 2020/2021 academic year. Various issues are milling about this, one of which is the issue of the abolition of Islamic religious education lessons. Researchers studied with a descriptive qualitative approach using content analysis techniques. Examine what strengthening is done through this policy. The results show that KMA 1832019 was born through an in-depth study. Systematic and measurable reinforcement. Aspects of attitude and behavior as the goal of Islamic religious education are emphasized. Moderate behavior is one of the strengthened goals. Keywords: PAI; KMA 183 2019; Strengthening
\end{abstract}

Abstrak: Penelitian ini bertujuan untuk menelisik esensi dari Keputusan Menteri Agama (KMA) nomor 183 tahun 2019. KMA 183 Tahun 2019 tentang kurikulum pendidikan agama Islam dan bahasa Arab di madrasah ditetapkan Menteri Agama untuk diimplementasi terhitung mulai tahun ajaran 2020/2021. Berbagai isu berseliweran tentang hal ini, salah satunya isu dihapusnya pelajaran pendidikan agama Islam. Peneliti mengkaji dengan pendekatan kualitatif deskriptif menggunakan teknik content analisis. Menelisik penguatan apa yang dilakukan melalui kebijakan ini. Hasilnya menunjukkan bahwa KMA 1832019 dilahirkan melalui kajian yang mendalam. Penguatan yang dilakukan sistemik dan terukur. Aspek sikap dan prilaku sebagai tujuan dari pendidikan agama Islam dipertegas. Prilaku moderat menjadi salah satu tujuan yang dikuatkan.

Kata Kunci : PAI; KMA 183 2019; Penguatan

Belajea: Jurnal Pendidikan Islam Vol. 6, No 2, 2021; 135-146

p-ISSN 2548-3390; e-ISSN 2548-3404, DOI: 10.29240/belajea.v6i2.3508

available online at:http://journal.iaincurup.ac.id/indek.php/belajea 


\section{PENDAHULUAN}

Baru-baru ini media sosial riuh dengan isu penghapusan mata pelajaran pendidikan agama Islam (PAI) dan bahasa Arab di madrasah. Surat Direktorat Jenderal Pendidikan Agama Islam Kementerian Agama No. B.1264/DJ.I/Dt.I.I/PP.00/07/2020 tertanggal 10 Juli 2020 tentang Implementasi KMA 792 Tahun 2018, KMA 183 Tahun 2019 dan KMA 184 Tahun 2019 dijadikan dalih hal ini. KMA adalah Keputusan Menteri Agama Republik Indonesia. Pada surat tersebut poin ketiga dijelaskan bahwa dengan berlakunya KMA 183 tahun 2019 dan KMA 184 tahun 2019 maka mulai tahun pelajaran 2019/2020 KMA nomor 165 tahun 2015 tentang Kurikulum 2013 Mata Pelajaran PAI dan Bahasa Arab di Madrasah sudah tidak berlaku lagi. Poin ini ditulis dengan huruf bolt yang menandakan perlu perhatian lebih. Jika kalimat ini dipotong, menjadi "Mata Pelajaran PAI dan Bahasa Arab di Madrasah sudah tidak berlaku lagi" maka maknanya menjadi sangat berbeda.

Ironinya, seringkali informasi invalid menyebar begitu cepat dan masif. Terlebih informasi yang menyangkut pada keyakinan pribadi dan emosional. ${ }^{1}$ Berbagai media sosial ramai dengan hal ini. Meskipun seringkali informasi tersebut belum jelas kebenarannya. Salah satu misalnya adalah kasus Ratna Sarumpaet yang diberitakan begitu heboh, berulang ulang, viral diberbagai media sosial bahkan juga diberitakan berbagai media elektronik nasional, sesungguhnya tidak terlepas dari berbagai kepentingan. ${ }^{2}$ Tingkat literasi yang rendah dan kemalasan menganalisa secara mendalam menjadikan hoax di share begitu saja dan menjadi viral. Isu-isu sensitif menjadi liar berkembang berkelindan dengan berbagai isu dan kepentingan lain. Pada tahun 2019 Menkominfo menyampaikan ada 1.645 hoax yang disebarkan dalam waktu 9 bulan sejak Agustus 2018-April 2019. Hal ini sebenarnya tidak aneh. Karena informasi hoaks ini ada produsennya. Pada tahun 2017 saja, Kementerian Komunikasi dan Informasi

${ }^{1}$ Dedi Rianto Rahadi, "Perilaku pengguna dan informasi hoax di media sosial," Jurnal Manajemen dan Kewirausabaan 5, no. 1 (2017): 58-70, http://files/162/Rahadi - 2017 - Perilaku pengguna dan informasi hoax di media sosi.pdf; Ilham Syaifullah, "Fenomena hoax di media sosial dalam pandangan hermeneutika" (UIN Sunan Ampel Surabaya, 2018), http://files/160/Syaifullah - 2018 - Fenomena hoax di media sosial dalam pandangan herm.pdf.

2 Ridwan Nasution dan S Sos, "Analisis Framing Tentang Pemberitaan Hoax Ratna Sarumpaet di Kompas.com dan Republika Online Rentang Waktu 02-05 Oktober 2018" 1 (2019): 6, http://files/72/Nasution and Sos - 2019 - Analisis Framing Tentang Pemberitaan Hoax Ratna Sa.pdf.

3 Effatha Gloria V.G. Tamburian, "Ditemukan 1.645 Konten Hoax Terkait Pemilu Serentak 2019," Gesturi.id, 16 Juli 2019, https://www.gesuri.id/pemilu/ditemukan-1-645konten-hoax-terkait-pemilu-serentak-2019-b1WeCZj0E. 
sudah mengidentifikasi 800.000 situs penyebar berita hoaks. ${ }^{4}$ Situs-situs ini memang mudah ditutup oleh Kominfo, namun akan segera lahir yang baru. Artinya cara ini efektif tapi tidak dalam jangka waktu yang lama.

Begitupun isu penghapusan mata pelajaran Pendidikan Agama Islam (PAI) ini, yang sebenarnya sudah lama ada. Isu ini hilang timbul. Pada tahun 2017 sempat menghangat setelah dikabarkan Menteri Pendidikan dan Kebudayaan Muhajir melontarkan ide ini. ${ }^{5}$ Majelis Ulama Indonesia (MUI) sempat menanggapi kabar ini, menganggapnya sebagai pelanggaran terhadap Undang-Undang Sistem pendidikan Nasional (Sisdiknas) Nomor 20 Tahun 2003. ${ }^{6}$ Meskipun kabar ini dibantah Mendikbud. ${ }^{7}$ Isu ini kembali menjadi viral dan menguat pada 2019. Pada suasana panas sebelum pemilu berkelindan dengan berbagai kepentingan. Kembali kabar ini ditolak oleh sang menteri. Ia mengklarifikasi bahwa itu tidak benar, ia justru menginginkan pelajaran agama diperkuat dengan pendidikan agama di luar sekolah. ${ }^{8}$

Penguatan pendidikan agama memang penting dilakukan. Terkait dengan berbagai problem pendidikan agama di negeri ini. Inilah maksud dari Keputusan Menteri Agama (KMA) 183 Tahun 2019. Menjadi penting untuk membaca ke mana arah penguatan Pendidikan Agama Islam yang diharapkan ditapaki madrasah-madrasah kedepan. Semua stakeholder penting memahami hal ini secara seksama. Pemahaman yang memadai akan menghindari kesalahpahaman. Bagi para pimpinan madrasah dan guru sangat penting untuk dapat dipahami arah baru pendidikan madrasah kedepan. Peneliti akan menggali perbaikan

\footnotetext{
${ }^{4}$ Ayu Yuliani, “Ada 800.000 Situs Penyebar Hoax di Indonesia,” Keminfo, 16 Juli 2017, https://kominfo.go.id/content/detail/12008/ada-800000-situs-penyebar-hoax-diindonesia/0/sorotan_media.

5 JPNN, "Kemendikbud Gagas Penghapusan Pendidikan Agama, Ini Suara MUI," PT. Jaringan Pemberitaan Nusantara Negeriku, 11 Juli 2017, https://www.jpnn.com/news/kemendikbud-gagas-penghapusan-pendidikan-agama-ini-suaramui; Rendy Sadikin, "Kemendikbud Bakal Hapus Pelajaran Agama di Kelas, Ini Pro dan Kontranya," Trbunnews, 11 Juli 2017, https://www.tribunnews.com/nasional/2017/06/14/kemendikbud-bakal-hapus-pelajaranagama-di-kelas-ini-pro-dan-kontranya?page $=$ all.

6 Abi Sarwanto, "MUI: Wacana Penghapusan Pelajaran Agama di Sekolah Langgar UU," CNN Indonesia, 11 Juli 2017, https://www.cnnindonesia.com/nasional/20170614125318-20221679/mui-wacana-penghapusan-pelajaran-agama-di-sekolah-langgar-uu.

7 Kemdikbud, "Mendikbud Bantah Akan Hapus Pelajaran Agama," Kemdikbud, 11 Juli 2017, https://www.kemdikbud.go.id/main/blog/2017/06/mendikbud-bantah-akan-hapuspelajaran-agama.

8 Zainal Ishaq, "Benarkah Pemerintah Akan Menghapus Pelajaran Agama Dari Sekolah?," Tempo.co, 11 Juli 2019, https://cekfakta.tempo.co/fakta/319/fakta-atau-hoaksbenarkah-pemerintah-akan-menghapus-pelajaran-agama-dari-sekolah.
} 
substantif apa saja yang diharapkan terjadi untuk menguatkan pendidikan agama Islam melalui implementasi KMA 183 Tahun 2019 ini kedepan.

\section{METODE}

Penelitian ini adalah penelitian kepustakaan (library research). Penelitian berbasis literatur ini akan menjadikan Keputusan Menteri Agama (KMA) No. 163 Tahun 2014 tentang Kurikulum Madrasah 2013 dan KMA 183 Tahun 2019 Tentang Kurikulum Mata Pelajaran PAI dan Bahasa Arab pada Madrasah sebagai sumber primer peneltian. Data sekunder akan memanfaatkan berbagai literatur terkait hal ini.

Penelitian ini menggunakan pendekatan kualitatif dengan teknik analisis content analysis. Peneliti akan menganalisa data yang ada untuk menjawab pertanyaan penelitian.

\section{PEMBAHASAN}

\section{Perbandingan KMA 164 Tahun 2014 dan KMA 183 Tahun 2019}

KMA No. 164 Tahun 2014 adalah KMA yang mengatur tentang pedoman kurikulum madrasah 2013 mata pelajaran Pendidikan Agama Islam (PAI) dan Bahasa Arab. Begitupun KMA 183 tahun 2019 juga merupakan KMA yang mengatur Kurikulum PAI dan Bahasa Arab di Madrasah. Artinya KMA 1832019 sebagai aturan yang baru me-nasikh-kan KMA 164 tahun 2014 sehingga menjadikan KMA 1642014 mansukh. Dengan demikian hal ini bisa dikatakan sebagai upaya pengembangan kurikulum PAI dan Bahasa Arab.

Pada aspek tujuan ada pengembangan atau perubahan arah yang signifikan. Pada KMA 164 Tahun 2014 tujuan kurikulum PAI adalah mempersiapkan manusia Indonesia agar memiliki kemampuan hidup sebagai pribadi dan warga negara yang beriman, produktif, kreatif, inovatif, dan afektif serta mampu berkontribusi pada kehidupan bermasyarakat, berbangsa, bernegara. Selanjutnya pada KMA 1832019 tujuan kurikulum PAI adalah untuk mempersiapkan manusia Indonesia agar memiliki pola pikir dan sikap keagamaan yang moderat, inklusif, berbudaya, religius serta memiliki kemampuan hidup sebagai pribadi dan warga negara yang beriman, bertakwa, berakhlak mulia, produktif, kreatif, inovatif, dan kolaboratif serta mampu menjadi bagian dari solusi terhadap berbagai persoalan dalam kehidupan bermasyarakat, berbangsa, bernegara dan peradaban dunia.

Dari tujuan ini terlihat ada penekanan pada sikap keagamaan moderat, inklusif, berbudaya dan religius. Ini merupakan salah satu target pembangunan. 
dalam Rencana Pembangunan Jangka Menengah Nasional (RPJMN) 2020-2024 yang disusun oleh Kementerian Perencanaan Pembangunan Nasional (Bapenas). Hal yang sebenarnya sesuai dengan konsep peran pendidikan agama Islam yakni kontra radikalisme.' Kementerian Agama juga sudah menyusun konseptual moderasi beragama melalui buku Moderasi Bergama. ${ }^{10}$ UNESCO sendiri menilai pendidikan berkualitas semestinya mengarah pada tolerasi, kedamaian, hak azazi manusia dan kewarganegaraan demokratis. ${ }^{11}$ Pendidikan berkualitas menghasilkan resolusi tanpa konflik. Apalagi Indonesia yang sangat multikultur, sangat penting setiap warga memiliki sikap moderat. ${ }^{12}$

Membangun sikap moderat, inklusif, berbudaya dan religius tentu menjadi tantangan bagi madrasah kedepan. Namun ini bukan hal yang tidak mungkin. Madrasah dapat membangun konsep yang pas agar mampu menjalankan program ini dan mencapai target. Beberapa sekolah telah mencontohkan hal ini, misalnya beberapa sekolah menengah atas (SMA) di Palu. ${ }^{13}$ Namun, kebijakan ini semestinya tidak hanya menyasar madrasah sebagai sekolah umat Islam. Konsep ini juga harus di kembangkan pada sekolah-sekolah agama lainnya. Sikap moderat, berbudaya dan religius harus menjadi bagian tujuan pendidikan dalam berbagai model. Dengan terbit dan dilaksanakannya KMA 1832019 ini, menjadi tantangan bagi Madrasah untuk menjadi pionir dalam mewujukan cita-cita besar ini.

Selain itu, pada KMA 1832019 ini Madrasah diharapkan ada peningkatan target yang tidak hanya sebagai warga negara namun sebagai bagian masyarakat dunia (global cityzenship). Artinya Madrasah diharapkan mempersiapkan siswanya untuk menjadi warga dunia yang dapat berkolaborasi untuk mendapatkan solusi problem dunia. Berbagai konsep kurikulum dibangun dengan menyasar tujuan ini, menjadikan pribadi-pribadi warga global. ${ }^{14}$ Kesiapan

9 Jose Antonio Rodríguez, "Islamic religious education and the plan against violent radicalization in Spain," Journal British Journal of Religious Education 41 (2019): 412-21, https://doi.org/https://doi.org/10.1080/01416200.2018.1484693.

${ }^{10}$ Badan Litbang dan Diklat Kementerian Agama, Moderasi beragama. (Badan Litbang dan Diklat Kementerian Agama RI, 2019), http:/ files/60/Indonesia and Badan Litbang Agama dan Diklat Keagamaan - 2019 - Moderasi beragama..pdf.

${ }^{11}$ Mary Joy Pigozzi, “A UNESCO View of Global Citizenship Education,” Educational Review 58, no. 1 (15 Juli 2006): 1-4, https://doi.org/10.1080/00131910500352473.

12 Amiruddin Amiruddin, Askar Askar, dan Yusra Yusra, "Development of Islamic Religious Education Learning Model Based on Multicultural Values," INTERNATIONAL JOURNAL OF CONTEMPORARY ISLAMIC EDUCATION 1, no. 1 (15 Juli 2019): 1-19, https://doi.org/10.24239/ijcied.Vol1.Iss1.2.

${ }_{13}$ Amiruddin, Askar, dan Yusra.

14 Namrata Sharma, "Value-Creating Perspectives and an Intercultural Approach to Curriculum for Global Citizenship," 2020, 16, http://files/70/Sharma - Value-Creating Perspectives and an Intercultural A.pdf. 
hidup bersama sebagai warga dunia masih dianggap UNESCO sebagai problem serius yang masih menghantui dunia saat ini. ${ }^{15}$

Artinya konektifitas global yang kuat saat ini menuntut pemahaman yang layak setiap pribadi sebagai warga global. Setiap pribadi dapat mengambil peran dalam mencari solusi berbagai problem dunia tanpa tersekat oleh teritorial. Selain itu, tentu saja diharapkan terbangun sikap saling paham akan tradisi atau budaya masing-masing wilayah, sangat variatif bahkan mungkin bisa saling bertolak belakang makna atau nilai antar daerah satu dengan yang lainnya. Kurikulum PAI melalui KMA 1832019 ini ingin membangun pribadi yang akrab dengan multikultur di berbagai belahan dunia.

Tujuan kurikulum PAI ini sebenarnya selaras dengan visi kementerian agama yang ingin mewujukan masyarakat yang religius dan rukun. ${ }^{16}$ Visi misi ini dibuat dengan diterbitkannya KMA nomor 39 tahun 2015. Artinya tujuan PAI tidak hanya taat beragama akan tetapi juga dapat berkolaborasi dengan yang lainnya. Sesuai juga dengan tujuan pendidikan yang dicanangkan UNESCO yakni learning to know, learning to do, learning to be dan learning to live together. Hal ini juga yang menjadi perhatian Delors pada pembukaan International Congress on Lifelong Learning pada 2011. ${ }^{17}$ The big goal pendidikan adalah dapat hidup bersama dalam keragaman.

Selain arah atau tujuan yang diperkuat, Pada KMA 183 tahun 2019, dijelaskan juga landasan kurikulum PAI dan Bahasa Arab yakni yakni landasan filosofis, sosiologis, psikopedagogis dan teoritik. Secara filosofis pengembangan kurikulum ini dilakukan karena pendidikan untuk kehidupan masa depan, agama untuk kebahagiaan dunia dan akhirat, sasaran utama PAI adalah mengelola hati, peserta didik adalah pewaris budaya bangsa, dan guru harus menjadi teladan. Landasan sosiologis pengembangan PAI tidak lain adalah kehidupan ini dinamis, PAI harus menanggapi kedinamisan ini. PAI diharapkan menjadi pendorong Madrasah menjadi agent of change. Dari aspek psikopedagogis PAI dipandang harus memenuhi konsepsi pedagogik transformatif yakni memperhatikan perkembangan psikologis, konteks lingkungan dan zamannya. Pada aspek teoritik yang menjadi landasan pengembangan kurikulum PAI ini adalah teori standar based education dan competency based curriculum. Kurikulum yang berlandasarkan target kompetensi menjadi kurikulum harapan kedepan.

${ }^{15}$ Pigozzi, “A UNESCO View of Global Citizenship Education.”

16 Kementerian Agama RI, "Visi Misi," 15 Juni 2015, https://kemenag.go.id/home/artikel/12433/visi-misi.

${ }^{17}$ Jacques Delors, "The Treasure within: Learning to Know, Learning to Do, Learning to Live Together and Learning to Be. What Is the Value of That Treasure 15 Years after Its Publication?," International Review of Education 59, no. 3 (15 Juli 2013): 319-30, https://doi.org/10.1007/s11159-013-9350-8. 
Kurikulum model ini telah menjadi tuntutan di berbagai negara dalam berbagai bidang. ${ }^{18}$

Artinya ini merupakan upaya peningkatan dengan melakukan standarisasi pendidikan agama Islam di Madrasah. Pada KMA sebelumnya hal ini tidak ada. Ini menggambarkan kurikulum PAI dan Bahasa Arab sesuai KMA 1832020 ini sudah melalui kajian yang mendalam. Ada hal-hal yang mendasari pengembangan yang dilakukan. Dari itu jumlah halaman KMA ini juga terlihat lebih banyak dari sebelumnya, pada KMA 1832019 ada 466 halaman, sedangkan KMA sebelumnya 321 halaman beserta lampirannya.

Pengembangan PAI melalui KMA 183 tahun 2019 berdasarkan beberapa rasionalisasi dimulai dengan menilik tantangan PAI kedepan baik dari internal maupun eksternal. Pada aspek tantangan internal, Madrasah masih dinilai belum mencapai tujuan secara masif bertakwa dan beraklak mulia. Artinya aspek sikap belum maksimal dan merata tercapai. Selain itu, adanya kecendrungan pola beragama yang tidak wasath yakni ekstrim-tekstualis dan sekuler-liberalis. Padahal ini merupakan cara beragama yang tidak substantif keluar dari kekhasan beragama bangsa Indonesia. Model beragama yang ekstrim inilah yang dapat merusak keutuhan bangsa, dapat memicu perpecahan NKRI. Pada sisi eksternal isu transnasional, lingkungan hidup, teknologi informasi, industri kreatif, budaya dan era disrupsi menjadi tantangan PAI kedepan.

Terkait tantangan ini, sebenarnya Ekonom Prancis Delors sudah lama mengingatkan, ia menyebutkan tiga tantangan pendidikan kedepan, yakni globalisasi, individualisme kontemporer serta media, teknologi dan ideologi ekonomi yang dominan. ${ }^{19}$ Globalisasi dimana dunia menjadi tanpa sekat, budaya menjadi mudah diadopsi oleh masyarakat global yang lain. Koneksi antar manusia dari berbagai elemen sangat mudah meski terpisah jarak. Individualisme kontemporer menurut Delors adalah problem yang banyak dialami masyarakat dunia. Ia menyebutnya kesepian dalam keramaian. Banyak yang merasa tidak lagi menjadi bagian dari komunitas. Semangat kompetisi menurunkan minat kerjasama. Media dan teknologi juga mempengaruhi pola pikir dan prilaku masyarakat. Delors menyebutnya dengan sindrom "cult of the present minute" dan

18 Stacey Chamberlain et al., "A global health capstone: an innovative educational approach in a competency- based curriculum for medical students," BMC Medical Education, 2020, 1-8; Cheptoo Ruth, "The 'Africanized' Competency-Based Curriculum: The Twenty-First Century Strides,” Shanlax 7, no. 4 (2019): 46-51, https://doi.org/https://doi.org/10.34293/ education.v7i4.640.

${ }^{19}$ Delors, "The Treasure within: Learning to Know, Learning to Do, Learning to Live Together and Learning to Be. What Is the Value of That Treasure 15 Years after Its Publication?" 
the "emotional society". Selain itu, menurutnya idologi yang menjadikan pasar penentu segalanya sangat merusak tatanan sosial.

Rasionalisasi berikutnya adalah penyempurnaan pola pikir. Upaya yang ditawarkan melalui kurikulum baru ini dengan mengubah pola belajar. Pola belajar teacher-centered diubah ke student-centered. Berbagai riset menununjukkan pengaruh positif penggunaan pola belajar student-center ini. ${ }^{20}$ Pola ini menuntut sistem belajar active learning. Selain itu, diharapkan memanfaatkan multimedia yang menjadikan proses belajar lebih menarik. Pada target, belajar PAI diharapkan tidak hanya menambah wawasan (knowledge) tapi juga mengubah sikap dan prilaku. Hubungan guru-siswa diharapkan terbangun mababbah fillah dalam upaya bersama mencapai keridhoan Allah.

Rasionalisasi ketiga adalah hingga penguatan tata kelola. Penguatan tata kelola ini berada pada lima pilar yakni keagamaan, kebangsaan, kemandirian, keumatan dan kemodernan. Penguatan tata kelola ini dari berbagai aspek baik guru, manajemen, nilai-nilai dan fokus.Artinya kedepan diharapkan madrasah membenahi diri dari berbagai aspek tata kelola.

Selanjutnya, melihat kompetensi inti dari kedua KMA, nyaris tidak ada perubahan berarti. Kedua nya menjelaskan keempat aspek kompetensi setiap kelas. Komptensi Inti (KI) yang disebut dengan KI-1 untuk aspek sikap spiritual, KI-2 aspek sikap sosial, KI-3 aspek pengetahuan dan KI-4 aspek keterampilan. Hanya bentuk tabel dilakukan perubahan, Pada KMA 183 2019, kompetensi inti di letakkan sejajar berada dalam satu baris (row) dilanjutkan kompetensi dasar di bawahnya. Sebelumnya kompetensi inti setiap aspek dijelaskan oleh kompetensi dasar yang sebaris dengannya. 4 kompetensi inti berada dalam 1 (satu) kolom (column) yang sama.

Namun jika dilihat ke kompetensi dasar, terlihat beberapa perubahan misalnya pada KI-2 terkait dengan sikap sosial. Pada Poin A al-Quran dan Hadis untuk MI kelas I semester ganjil pada KMA sebelumnya capaian kompetensi dasar yang menjadi ukuran adalah terbiasa membaca al-Quran dengan benar dan baik sesuai hukum tajwid dan terbiasa mengamalkan kandungan surat al-Fatihah, an-Nas, al-Falaq, al-Ikblas dan al-Lahab. Pada poin membaca al-Quran dengan baik dan benar tidak ada masalah, namun mengamalkan beberapa surat tersebut cukup sulit diukur. Problemnya adalah pemahaman tentang surat-surat tersebut

${ }^{20}$ Mujtaba Saeed Arman, "Student-centered approach to teaching: It takes two to tango," The Ahfad Journal 35, no. 2 (2018): 64-71; Gezim Bara dan Nazmi Xhomara, "The Effect of Student-Centered Teaching and Problem-Based Learning on Academic Achievement in Science," Journal of TURKISH SCIENCE EDUCATION 17, no. 2 (2020): 180-99; Natalya V Solovova et al., "Realization of Student-Centered Approach in Learning Environmental Knowledge," Ekoloji 27 (2018): 2095-2103. 
akan cukup luas. Wajar kemudian hasil kajiannya menunjukkan belum tercapainya secara masif aspek sikap sosial pada siswa. Hal inilah yang disebutkan pada KMA 1832019 sebagai salah satu tantangan internal.

Pada KMA 183 kompetensi dasar pada KI-2 (sikap sosial) tersebut diubah, menjadi menunjukkan sikap disiplin dalam kehidupan sehari-hari dan mengamalkan sikap percaya diri sebagai mukmin. Ini lebih jelas dan tegas menjadi mudah terukur. Begitupun pada kompetensi dasar KI-2 kelas 1 semester genap, dilakukan perubahan. Kompetensi dasar versi KMA 1652014 memang 'aneh'. Antara kompetensi inti dengan kompetensi dasarnya berselisih. Kompetensi intinya memiliki sikap jujur, disiplin, tanggung jawab, santun, peduli, dan percaya diri dalam berinteraksi dengan keluarga, teman dan guru. Salah satu kompetensi dasarnya membiasakan membaca huruf hijaiyah sesuai mahraj dan tanda baca. Bagaimana bisa kompetensi dasar ini mencapai titik akhirnya kompetensi inti, cukup sulit. Kalaupun sampai pada kompetensi inti jalannya berputar-putar terlalu jauh. Pada KMA 1832019 kompetensi dasar tersebut diubah menjadi mengamalkan sikap disiplin dan berprilaku santun kepada orang tua, keluarga, teman dan guru. Begitupun kompetensi dasar berikutnya, terkhususnya pada sikap sosial, dilakukan perubahan.

Pada KI-3 (pengetahuan) kompetensi dasarnya juga diubah. Pada mata pelajaran a-Quran Hadis kelas I semester ganjil diksi yang dipilih pada KMA 165 2014 adalah mengetahui dan mengenal sedangkan pada KMA 1832019 ditingkatkan menjadi memahami. Hal ini dinyatakan meningkat karena memahami dalam Kamus Besar Bahasa Indonesia $\mathrm{V}$ diartikan mengetahui benar. Hal ini sebenarnya terlihat sepele padahal pemilihan diksi ini memberi dampak kejelasan tujuan. Kejelasan tujuan sangat penting bagi guru dalam membuat perencanaan pembelajaran.

Kompetensi dasar pada aspek keterampilan (KI-4) juga diubah. Sebelumnya dipilih diksi membaca dan menghafal sedangkan yang terbaru mendemonstrasikan dan melafalkan. Mendemontrasikan memiliki arti lebih luas, tidak hanya membaca tapi juga mempertontonkan, memperagakan. Namun diksi melafalkan ini menurun jika dibandingkan dengan keterampilan menghafal. Meskipun jika mempertimbangkan waktu belajar menghafal akan lebih sulit dicapai, melafalkan lebih memungkinkan. Apalagi untuk anak usia 7 tahunan tentu lebih menantang lagi. Anak usia awal sekolah masih dalam tahap memahami hal-hal sederhana. ${ }^{21}$ Namun, menghafal bisa menjadi pilihan yang baik dalam bentuk penugasan. Jika dilihat lebih jauh ternyata kompetensi dasar ini tidak benar-benar dihapus, ini muncul di kompetensi dasar KI-4 (keterampilan) pada kelas III semester ganjil. Artinya pertimbangan

${ }^{21}$ Overby Jeanna, Development Psychology (Delhi: The English Press., 2012). 
perkembangan anak menjadi perhatian dalam KMA 1832019 ini dalam menetapkan kompetensi yang akan dicapai.

Artinya perubahan kurikulum ini ini sudah sangat sistemik. Memenuhi kriteria kurikulum yang baik sebagaimana disampaikan Mendikbud (2009-2014) Muhammad Nuh. Ia menyatakan bahwa kurikulum yang baik secara manajemen paling tidak harus memenuhi 4 hal yakni kompetensi lulusan, materi, proses pembelajaran dan evaluasi. ${ }^{22}$

\section{KESIMPULAN}

Memilik perbedaan diatas dapat dipahami bahwa banyak penguatan yang akan dilakukan melalui KMA 1832019 ini. Perubahan kurikulum pendidikan agama Islam dilakukan secara sistemik dan terukur. Pengembangan didasari oleh landasan filosofis, sosiologis, psikopedagogis dan teoritik serta rasionalisasi. Kompetensi dasar didesain dengan memperhatikan berbagai aspek termasuk perkembangan anak. Aspek sikap sosial mendapat porsi perhatian yang lebih terlebih sikap moderat beragama.

\section{BIBLIOGRAFI}

Amiruddin, Amiruddin, Askar Askar, dan Yusra Yusra. "Development of Islamic Religious Education Learning Model Based on Multicultural Values." INTERNATIONAL JOURNAL OF CONTEMPORARY ISLAMIC EDUCATION 1, no. 1 (15 Juli 2019): 1-19. https://doi.org/10.24239/ijcied.Vol1.Iss1.2.

Arman, Mujtaba Saeed. "Student-centered approach to teaching: It takes two to tango." The Ahfad Journal 35, no. 2 (2018): 64-71.

Bara, Gezim, dan Nazmi Xhomara. "The Effect of Student-Centered Teaching and Problem-Based Learning on Academic Achievement in Science." Journal of TURKISH SCIENCE EDUCATION 17, no. 2 (2020): 180-99.

Chamberlain, Stacey, Nicole Gonzalez, Valerie Dobiesz, Marcia Edison, Janet Lin, dan Stevan Weine. "A global health capstone: an innovative educational approach in a competency- based curriculum for medical students." BMC Medical Education, 2020, 1-8.

Delors, Jacques. "The Treasure within: Learning to Know, Learning to Do, Learning to Live Together and Learning to Be. What Is the Value of That Treasure 15 Years after Its Publication?” International Review of Education 59,

${ }^{22}$ Muhammad Nuh, “Kurikulum 2013,” Kompas, 2013. 
no. 3 (15 Juli 2013): 319-30. https://doi.org/10.1007/s11159-013-9350-8.

Gloria V.G. Tamburian, Effatha. "Ditemukan 1.645 Konten Hoax Terkait Pemilu Serentak 2019." Gesturi.id, 16 Juli 2019. https://www.gesuri.id/pemilu/ditemukan-1-645-konten-hoax-terkaitpemilu-serentak-2019-b1WeCZj0E.

Ishaq, Zainal. "Benarkah Pemerintah Akan Menghapus Pelajaran Agama Dari Sekolah?” Tempo.co, $11 \quad$ Juli 2019. https://cekfakta.tempo.co/fakta/319/fakta-atau-hoaks-benarkahpemerintah-akan-menghapus-pelajaran-agama-dari-sekolah.

Jeanna, Overby. Development Psychology. Delhi: The English Press., 2012.

JPNN. "Kemendikbud Gagas Penghapusan Pendidikan Agama, Ini Suara MUI." PT. Jaringan Pemberitaan Nusantara Negeriku, 11 Juli 2017. https://www.jpnn.com/news/kemendikbud-gagas-penghapusanpendidikan-agama-ini-suara-mui.

Kemdikbud. "Mendikbud Bantah Akan Hapus Pelajaran Agama." Kemdikbud, 11 Juli "Me17. https://www.kemdikbud.go.id/main/blog/2017/06/mendikbud-bantahakan-hapus-pelajaran-agama.

Kementerian Agama, Badan Litbang dan Diklat. Moderasi beragama. Badan Litbang dan Diklat Kementerian Agama RI, 2019. http://files/60/Indonesia and Badan Litbang Agama dan Diklat Keagamaan - 2019 - Moderasi beragama..pdf.

Nasution, Ridwan, dan S Sos. "Analisis Framing Tentang Pemberitaan Hoax Ratna Sarumpaet di Kompas.com dan Republika Online Rentang Waktu 02-05 Oktober 2018" 1 (2019): 6. http://files/72/Nasution and Sos 2019 - Analisis Framing Tentang Pemberitaan Hoax Ratna Sa.pdf.

Nuh, Muhammad. "Kurikulum 2013.” Kompas, 2013.

Pigozzi, Mary Joy. "A UNESCO View of Global Citizenship Education." Educational Review 58, no. 1 (15 Juli 2006): 1-4. https://doi.org/10.1080/00131910500352473.

Rahadi, Dedi Rianto. "Perilaku pengguna dan informasi hoax di media sosial." Jurnal Manajemen dan Kewirausahaan 5, no. 1 (2017): 58-70. http:/ files/162/Rahadi - 2017 - Perilaku pengguna dan informasi hoax di media sosi.pdf.

RI, Kementerian Agama. "Visi Misi," 15 Juni 2015. https://kemenag.go.id/home/artikel/12433/visi-misi. 
Rodríguez, Jose Antonio. "Islamic religious education and the plan against violent radicalization in Spain." Journal British Journal of Religious Education 41 (2019):

412-21. https://doi.org/https://doi.org/10.1080/01416200.2018.1484693.

Ruth, Cheptoo. "The 'Africanized' Competency-Based Curriculum: The Twenty-First Century Strides." Shanlax 7, no. 4 (2019): 46-51. https://doi.org/https://doi.org/10.34293/ education.v7i4.640.

Sadikin, Rendy. "Kemendikbud Bakal Hapus Pelajaran Agama di Kelas, Ini Pro dan Kontranya." Trbunnews, 11 Juli 2017. https://www.tribunnews.com/nasional/2017/06/14/kemendikbudbakal-hapus-pelajaran-agama-di-kelas-ini-pro-dan-kontranya?page $=$ all.

Sarwanto, Abi. "MUI: Wacana Penghapusan Pelajaran Agama di Sekolah Langgar UU." CNN Indonesia, 11 Juli 2017. https://www.cnnindonesia.com/nasional/20170614125318-20221679/mui-wacana-penghapusan-pelajaran-agama-di-sekolah-langgar-uu.

Sharma, Namrata. "Value-Creating Perspectives and an Intercultural Approach to Curriculum for Global Citizenship," 2020, 16. http:// files/70/Sharma - Value-Creating Perspectives and an Intercultural A.pdf.

Solovova, Natalya V, Tatyana V Samodurova, Lenar R Khairullin, dan Anna V Filippova. "Realization of Student-Centered Approach in Learning Environmental Knowledge." Ekoloji 27 (2018): 2095-2103.

Syaifullah, Ilham. "Fenomena hoax di media sosial dalam pandangan hermeneutika." UIN Sunan Ampel Surabaya, 2018. http:// files/160/Syaifullah - 2018 - Fenomena hoax di media sosial dalam pandangan herm.pdf.

Yuliani, Ayu. "Ada 800.000 Situs Penyebar Hoax di Indonesia." Keminfo, 16 Juli 2017. https://kominfo.go.id/content/detail/12008/ada-800000-situspenyebar-hoax-di-indonesia/0/sorotan_media. 